\title{
Migration, Youth and Social Issues in Albania: Kukes Region Case
}

\author{
Enkelejda Cenaj, Phd candidate \\ Faculty of Education, "Aleksander Moisiu" University, Durres. \\ e-mail: enicenaj@gmail.com
}

Doi:10.5901/mjss.2013.v4n10p693

\begin{abstract}
This research was conducted to investigate the realities on the social issues that disturb the everyday living of youth in Albania, focusing on the case of the Kukes Region, by gathering quantitative and qualitative data. Kukes Region suffers from a wide range of socio-economical issues that make the life of the inhabitants difficult and induce them to leave the region. Migration of the population, especially of youth, is one of the main issues that disturb the region. Youth activism has always played an important role in the development of the society and Kukes region is compound by a relatively young age population. In this research 150 people were invited to participate in the questionnaires, 15 people in the opened interviews. The findings revealed that youth in Kukes Region find it difficult to live in the region because of the wide range of social issues like poverty, unemployment, gender issues, etc.
\end{abstract}

Keywords: youth; development; employment; education; migration; Kukes Region; patriarchal society; old mentality;

\section{Introduction}

The Kukes Region lies in the northeastern part of Albania and includes three districts: Kukes, Has and Tropoja, with a population of 114,000 inhabitants (data taken from the Kukes Regional Council). It consists of 3 municipalities, 24 communes, 187 villages (89 villages in the Kukes District, 30 in Has District and 68 in Tropoja).

This region is considered as one of the poorest regions in Albania. In 2010 the number of the families that benefited economical aid was 1027 families per 10.000 inhabitants (The Regional Development Strategy, 2012-2016, page 20).

A wide range of socio-economical issues disturb the life of the inhabitants in this region, making difficult the everyday living. According to the Regional Development Strategy ${ }^{1}$ some of the factors that have contributed in increasing of the rates of poverty in the region are as below:

$>$ Increased unemployment, deteriorated from destruction of state enterprises, which were the biggest providers of job opportunities.

$>$ The fall of pyramidal schemes ruined the finances and financial savings for the majority of population.

$>$ Agricultural activities in the region lack of tools for production manufacture. Even if the tools existed, the remote area, lack of transportation infrastructure, lack of electrical and running water would make no use of them.

$>$ Lack of functional and modern education environments has caused the increase of school drop outs.

$>$ Patriarchal tradition and gender inequality in another social issue that needs to be addressed.

$>$ Lack of national and international investments in the region. Also the misuse of the natural recourses which are available in the region.

$>$ Lack of equality in providing social, health and education services in the remote areas because of the low population density and natural difficult conditions that characterize the region.

$>$ Dependence on the economical aid, $45 \%$ of the families in the region are treated with social aid.

$>$ Lack of youth involvement in decision-making. We have to remind that Kukes Region has a relatively young age population.

$>$ Villages are in a much worse conditions. Because of the bad living conditions most of them are abandoned.

${ }^{1}$ For more information refer to "The Strategy of Kukes Region Development, January, 2004", page 77-78 and to "The Regional Development Strategy $(2012-2016) "$. 
All these socio-economic problems were accompanied with another disturbing phenomenon, the migration of the population. A considerable number of the inhabitants, especially youth generations, moved to live in other cities or abroad. In the Development Strategy for the Kukes Region it is stated that "The most important recourses in the region are its inhabitants" (SZHQK, 2004: 10), and these recourses were departing.

We all know the consequences of the migration of the population in the development of this region. Among the inhabitants that left the region were doctors, teachers and educated people that had given an important contribution in offering qualitative services to this region, also simple, hard working people and the youth who were the future of this region. Not only the cities, but especially the villages, were abandoned and as a result and infrastructure and development were aggravated continuously. From 1989 to 2001, 25\% of the population moved from the Kukes Region (SZHQK, 2004: 36).

"Why stay? There is nothing for me here. I do not have a job and I do not have running water! We have just each other and this in not enough for me right now." - Student from Kukes Region (SZHQK, 2004: 40).

Poverty, unemployment are disturbing phenomenon for the Kukes Region, but the growth of the number of inhabitants that migrate (especially youth), the increased desire of the inhabitants to move from the region and live somewhere else is a worse social issue for the region. Especially youth, who find the life in Kukes region difficult and frustrate.

Kukes Region is compounded by a relatively young population, the average age of the population is 26.9 years old, $54 \%$ of the population is under 25 years old (SZHQK, 2004: 38). Youth is a very important agent for the development of this region, but they want to leave if they have the opportunity. In this article I tend to investigate what youth think about living in the region? What are the main social issues that according to them make their life difficult in the region and make them wanting to leave or not to return back?

\section{Methodology}

Instruments: The instruments used in this study are: first, data gathered from the local institutions like Regional Council, Regional Education Directory, Kukes Prefecture; secondly, 150 questionnaires and 15 interviews are administered; thirdly, direct observations, a method facilitated by the fact of being an inhabitant of one of the districts of the Kukes Region.

From data analyzes the sample results as follows:

\begin{tabular}{c|c|c|c}
\hline Age & Female & Male & Total \\
\hline $18-24$ year & 40 & 45 & 85 \\
\hline $25-30$ year & 30 & 35 & 65 \\
\hline Total & 70 & 80 & 150 \\
\hline
\end{tabular}

In the sample 30 of the respondents were emigrant that live abroad, 60 of them were students who were attending the university in Tirana and Durres, 60 others live in the Kukes region.

\section{Results and Discussions}

\subsection{Staying or leaving the region?}

a) The respondents that were attending university studies in Tirana and Durres were asked: If they would prefer to stay and live in Tirana after finishing their studies?

From data analyzes $70 \%$ of the respondents responded positively. The respondents that answered maybe $(20 \%)$ or no (10\%) were mostly students on their first years of their studies.

One of the male respondents, aged 21, stated: "I do not want to go back there. I will do anything not to go back"

"Turn back? Are you kidding me? Back in my home there is nothing to do, just work in the field and drive three hours to go in the city. I come from a village where there is only one grocery shop, a bar for men and nothing else. Who would want to go back in a place like that? I am in the second year and I am looking for a job so I 
can stay even during summer in Tirana. Thank God my brother, who lives abroad, is helping me with money for the moment" stated another male respondent, aged 20;

Another male respondent, aged 21, stated: "If we could choose, I think that no one would want to go back. Every student from all over Albania would like to live in Tirana because it is the city that can offer more opportunities. But, you have to have a job to stay or a rich family because life here is very expensive. So, if I find a job here, I will stay, if not, I do not have another choice but go back".

"If I want to stay, yes I do. If I will stay, No I won't. My family won't let me live here, they want me back after finishing my studies. You know, for a girl is not so easy to decide to stay because girls cannot take those decisions" stated a female respondent, aged 20.

Another female respondent, aged 19, stated: "After my studies I would like to find a job in Tirana and live there. I want that but I have to convince my family to let me. My brother seems to not liking the idea much. He says that I can do that after I get married".

In nowadays there are a lot of young people from Kukes Region that after their studies have stayed to live and work in Tirana. According to the results, the respondents state that they would prefer to stay in Tirana after their studies, some of them have done that, some of them have returned. According to the results, staying or leaving in not a free decision for girls because of the patriarchal society and the old mentality on gender roles. A respondent that has finished her studies and decided to stay and live in Tirana stated: "It was a tough decision, I went against all my family. They did not want me to come here. They still tell to me that I have done a mistake and if I had returned life would have been much easier for me. Most of the time I cannot complain to them if something is wrong, like the wage that never is enough for example, because every time they toss it as a sign of their victory. It is not easy for a girl to decide to leave her family and live alone, while not being married. In the region people are not used with women independence. You do not imagine what people say about girls and women that have dared to challenge the old mentality, but I do not mind actually, my family does".

b) The respondents that actually live in the region were asked: If they would prefer to live somewhere else than in the region, the results were: Yes - 64\%; No - 14\%; Maybe -17\%, I don't know - 5\%.

One of the male respondents, aged 27, stated: "If I had some money I would have already gone".

Another male respondent, aged 28, stated: "I want to go away; actually I am planning to do that again. I tried once, but I got caught after three months. It was a difficult experience but I will try again. I have nothing to do here, no job, no money, nothing....".

A female respondent, aged 24, stated: "I would like that, not because I do not like it here, but there are so many problems that make our life so difficult that anything else would look better".

"Look around where I live...everyday is the same, everyday is like a battle to survive. No one in my family works; I haven't attended school, my children either, because there is not one in our village...I am sorry for the great view we have, but I can't live only with it.." stated a female respondent, aged 30.

According to the results, the life is so difficult in the region, especially in the villages that they would change it to go somewhere else where there are more possibilities for them. The respondents stated that the region was blessed with a beautiful nature, but it lacks so many necessary services and facilities to benefit from it. One of the female respondents stated: "We have so many vital issues to resolve than enjoying the scenery around. How you can do that where you do not have a job, when you are afraid to get sick because the hospital is so far, when your kids stay around all day because the school is far and the roads are wrecked..".

c) The respondents that live abroad were asked if they have considered coming back to live in their birth place in the future? The results show that they would prefer to comeback to visit or spend the vacations here, but the everyday life will be the one in the country where they have migrated.

One male respondent stated: "I love my birthplace but it is very difficult to live there. I will just come back for vacations, to visit relatives, but that's it".

Another respondent, female, stated: "I came here when I got married. I have a much better life here, I go out in the evening, my husband has a good job, life is much better. My life in my village was boring, all days the same. It was boring and tiring, all those chores to do, inside the house and in the field, money were never enough". 


\subsection{What are the main social issues that induce the respondents to consider leaving the region?}

Regarding to the data gathered, the main social issues that disturb the life of youth (and not only) and make them want to leave or not coming back, are as follows:

\subsubsection{Poverty related issues and life conditions in the Kukes Region;}

According to the respondents, one of the social issues that disturb their life is poverty. Related to the poverty, life conditions in Kukes region are one of the main social issues that induce youth to leave the region. The situation is critical especially in the distant villages, where there is lack of educational system, health system, even of running water in their homes and electricity.

This makes this region not attractive for youth to live.

\subsubsection{Lack of road-infrastructure development;}

The undeveloped road infrastructure is seen as one of the main issues that induce the youth in Kukes region to leave. The construction of Durres-Kukes road has improved the national road infrastructure and connection with other cities especially for the Kukes district, but still the region suffers from the lack of road infrastructure. The connection of the other districts, Tropoja and Has, with other cities, and especially the connection of the villages with each other and especially with the cities is problematic. The bad and undeveloped road infrastructures make the life of inhabitants very difficult, and induce them to leave. A considerable number of villages are abandoned because of the bad infrastructure. Youth who live in the villages are faced with a wide range of social issues every day. One of the respondents stated: "I live in a village that takes 2 hours to go to the city. You can travel only early in the morning because the van goes early in the city and comes back in the evening. During the winter we stay months without going anywhere. The life here is the same, help in some field work, watch television ....it is boring".

\subsubsection{Unemployment;}

The job market in the Kukes Region continues to be poor by resulting in high levels of unemployment in this region. The public job market is focused mostly on offering services and the production sector has not been developed after the closure of factories after 1990. The private sector is small and undeveloped and mostly includes fields such as building industries, transport, marketing, etc., (District Council, 2006: 48-49). Lack of job opportunities is considered as one of the main factors that induce youth to leave their birthplace. In the villages the scenario is even worse, where agriculture is the only activity that the families conduct for their living.

\subsubsection{Carrier and professional growth;}

Most of the respondents state that in their birthplace it is very difficult to advance in their professional growth and qualifications. Job opportunities are few in the region, so few that you should feel lucky just to have a job. The situation is worse in the villages where working in the field is usually the only activity available for the inhabitants. In this case growing professionally or being promoted is just out of question.

One of the female respondents that works in a Bank in Kukes city stated: "The only opportunity for being promoted is to be engaged in politics and to be lucky enough that the political party that you support will be the one that governs".

The interviewees state that if they are lucky enough to find a job, the only thing they have to do is to keep the job. A female respondent aged 30 stated: "I work in this job for 8 years now, nothing is changed. I just have to feel lucky enough that I have the job, growing up in duty seems out of the question".

According to the respondents, for women and girls is much more difficult to grow professionally because of her gender roles and the patriarchal society. A female respondent, aged 28, stated: "we only are in XXI century with years because life has not changet much for girls and women. The role of girls and women is the same as a century before, despite what it looks like. In family man are in charge, at job men are in charge, whereever you look you see only men, in the street, in the directors offices, in the head of the table.....".

Acording to the respondents, the main reasons that make it difficult to promote or grow preffesionally are as below: 
- leading job possitions usually are asigned politically and not by merit;

- there aren't many job possibilities availablel in the region; having a job is being lucky;

- girls and women are penalized on promoting because of the patriarchal society and old mentality on gender roles;

- the private sector is undeveloped in the region, so the job opportunities in this sector are not many; also, the branch of private sectors that operate in the region (construction, transportation, etc.) do not offer much opportunities for promotion or professional growth;

\subsubsection{Entertainment possibilities;}

Social and cultural life in the Kukes Region almost does not exist. The possibilities to be entertained in this region are reduced in having coffee in the city bars and for the youth that live in the villages, social and cultural life is even more difficult. There is no cinema, art gallery or other entertaining and cultural activity in the region, as one of the respondent stated: "Here you have to wait for the electoral campaigns to begin so you can have the opportunity to attend a concert in the city".

Cultural and entertainment activities are very few in the cities, only in some show organized for New Year feast, or some other special occasion. The situation in the villages is worse, there is difficult to find services that are necessary for the welfare of the inhabitants, looking for entertainment is a question of luxury.

A female respondent that lives in a village stated: "My only entertainment is the television. You can watch others how they life their life, feel miserable about yours, and desire with all your heart to find a way to escape. A lot of girls here in the village are married just to go away from here and not because they were in love".

\subsubsection{Old mentality and patriarchal society;}

The respondents think that living in their birthplace is difficult because of the old mentality, opinions and rumors that cause them frustrations and violates their freedom. Much more than boys, girls suffer more the weight of the old mentality and rumors. According to them, in their birthplace people like to talk about the others more than tend to look their own business. "Eat your bread and talk to the others" stated a respondent. It is better to live in Tirana where no one knows you and vice versa.

People in Kukes region know each other very well and they live so close to each other that they cannot ignore the other's opinion. The old mentality is harsher on girls and women. Girls and women have to stay in their homes, take care of their domestic duties. Outside business, decision making are man's matter. Regarding to this issue a female respondent stated: "A good girl and women is one that cleans, cooks, and obeys. Girls and women that seek higher education, go at work are usually rumored around from the others".

\subsubsection{Gender inequality}

Kukes region society is a traditional one, characterized by patriarchal elements. The female respondents stated that gender issues are one of the main problems that make their life difficult in their birth place. A female respondent stated: "For girls in not as easy as for boys here. Life is much more difficult for us. While unmarried, your father and brother try to control you, after marriage their place is taken by your husband".

Because of the patriarchal society and different social conditions in which women and men are faced with, everyday living is not handled the same between men and women, boys and girls. The social issues are hard on women and girls and as a result their life is much more difficult. A female respondent aged 29 stated: "The life is very hard for a girl here, always being judged, always being surveyed by the other. It feels like you have to report for everything you have done or not done; always to ask permission for what you want to do...".

Another female respondent stated: "You do not have control on your life. If you want to do something you have to ask for permission, even to go shopping. My brothers are abroad, living their life, they did not ask anyone to go or not, they just did".

In Kukes region most women and girls:

- Depend economically on their husband, father or family;

- Unemployment rate is higher among women than men; 
- Because of their family duties they put their career aside to hold their family, especially when children are involved;

- Gender roles like being a housewife, taking care of cooking, cleaning and raising children, isolates women within the walls of their homes and make them dependent to their husband or father for everything that the family needs from outside these walls, like incomes to afford the life.

\section{In conclusion}

The youth in Kukes region are faced with a wide range of social issues that disturb their life. Unemployment, lack of basic services, lack of infrastructure, gender inequality, disturbs their life, making every day a challenge. Girls are discriminated more than boys because of the old mentality and patriarchal society. The youth living in the villages are faced with much more difficulties that the one that live in the cities. The remote areas, cold long winters, bad roads, lack of infrastructure, are just some of the social issues. From the results, the respondents state that they would prefer to live somewhere else if they have a choice.

\section{References}

Albania NGO Shadow Report (2002). Convention On The Elimination Of All Forms Of Discrimination Against Women (CEDAW). OMBRA GVG VISUAL. TIRANA.

Dervishi, Z. (2001). Gratë në syrin e ciklonit të sfidave dhe perspektiva. Tiranë. Shtëpia Botuese Jerusalem.

Department Strategy and Donor Coordination, Council of Ministers, Republic of Albania (2009). National Strategy for Development and Integration, Progress Report, November, Tirana.

Halilaj, Isa (2002). Kukes in the table of national education: Educational developments in the Region of Kukes (Kukes, Has, Tropoja) 1944-2000, Geer Publishing House, Tirana.

Fuga, Artan (2004). Shoqëria Periferike, Sociologji e Ndryshimit në Shqipëri. Ora, Tirana.

Fuga, Artan. and Dervishi, Zyhdi (2002). Ndërmjet Fshatit dhe Qytetërimit Global. Integrimi Shoqëror i të Rinjve të Zonave Fshatare në Dritëhijet e Arsimimit të Mesëm. Trajtesë Sociologjike, Jerusalem, Tirana.

INSTAT (2007). Indicators By Prefectures, Tirane.

INSTAT (2004). Migracion in Albania: Population and Housing Cernsus, Tirane.

INSTAT (2004). People and Work in Albania, Labour Force, Employment and Unemployment, Tirana.

INSTAT (2004). Predictions for the population of Albania 2001 - 2021, Tirana.

INSTAT (2007). Albania in Figures 2007, Tirane.

INSTAT (2005). Indicators by Prefectures, Tirane.

INSTAT (2004). Living conditions and inequality in Albania, Tirana.

INSTAT (2004). Perspektiva gjinore në Shqipëri. Tiranë.

INSTAT (2007). Femrat dhe Meshkujt ne Shqiperi. Tiranë.

Jenkins, L. et al. (1998). Albanian's Road to Democracy, A Fascinating Country in Transition. ORT/USAID. Democracy Network Program. Washington. DC.

Institute of Statistics, Institute of Public Health [Albania] and ICF Macro (2010). Albania Demographic and Health Survey 2008-09. Tirana, Albania.

Jenkins, Lori (Principal Researcher) etc (1998). Albanian's Road to Democracy, A Fascinating Country in Transition, Washington, DC.

Kukes Regional Council Kukes Regional Council (2012). The Regional Development Strategy (2012 - 2016). Qershor.

Kukes Regional Council (2004). The Strategy of Kukes Region Development, January (SZHQK).

Ministry of Economy, Trade and Energy (2007). Cross-Regional Development Strategy, September. Statistical data, http:/l www.instat.gov.al

UNICEF Albania (2000). Assesment of Social and Economic Conditions of Districts in Albania, December.

UN-INSTRAW and UNDP (2010). Migration, remittances and local development that responds to gender needs: the case of Albania. Tirana. 